The success of the scheme is shown by the fact that it has resulted in a considerable profit; of this one half has been returned to the subscribers in the form of additional whole-plate photographs, and the other half will provide funds for carrying on the work of the committee for at least four years. In a strictly business undertaking it is to be presumed that a good slice of the profits would disappear in "wages of superintendence," and subscribers may therefore regard their additional photographs as a gift from Prof. Watts.

\section{THE SOCIETY OF ARTS AND THE LONDON INSTITUTION.}

$\mathrm{O}^{\mathrm{N}}$ Wednesday next a special meeting of proprietors of the London Institution will be held to consider a scheme for its amalgamation with the Society of Arts. Founded in 1805 by merchants and bankers of the City of London, given a charter two years later, and housed in its present imposing, if rather sombre, premises in 1819 , the London Institution has done good work in its day. The object of its founders was to maintain, in what was then a central position, an extensive general library of reference, comprising works of intrinsic value and utility in all languages; to provide reading rooms for periodical publications and interesting contemporaneous pamphlets; and to promote the diffusion of knowledge by lectures and conzersazioni. But since the foundation of the institution circumstances have greatly changed, and not to the advantage of the institution. In $18 \mathrm{r} 7$, and for many years afterwards, the City contained a large residential population, which for a long time past has been gradually disappearing, until now the number of proprietors who use the institution as a centre of intellectual culture is comparatively small, and is more likely to srow smaller than to increase. In these circumstances the board of management has recognised that if the institution is to live and thrive some scheme must be devised for increasing its usefulness, and the proposal to amalgamate with the Society of Arts is the outcome of prolonged consideration of a difficult problem.

The Society of Arts carries on to a large extent work of the same nature as that for which the London Institution was founded, but whereas the institution has suffered from residential changes, the society was never more prosperous. But it, too, has had its ups and downs. In the early 'forties of the last century it began to show signs of decrepitude, and in $184 \mathrm{r}$ a committee was appointed to examine its position and make recommendations. But little seems to have been done until measures were taken for obtaining a Royal Charter of Incorporation, which was granted in 1847 . Then it was proposed to hold an exhibition of English industry. Prizes for modern industrial art were offered, and eagerly competed for, and by 1850 the membership had risen again to 1500 . An exhibition of ancient and mediæval art was held which was very successful, and a proposal to hold an international exhibition culminated in the Great Exhibition of $x 8_{5} \mathrm{r}$. Since then the Society of Arts has done much good work in promoting industrial art and encouraging inventive genius. The prosperity of the 'fifties was followed by some lean years, but for a generation past it has been highly prosperous, largely owing to the sagacious guidance of its present secretary. Sir Henry Wood has always attached great importance to the constitution of the council of the society. He has not only sought for and found eminent men, he has got those who were willing to give time and attention to the affairs of the society, men like Sir Frederick Bramwell, Sir F. Abel, Sir W. Siemens, Sir Douglas Galton, Lord Alverstone, Sir J. W. Barry, Sir WV. Preece, the Duke of Abercorn, No. I849, voI. 7 I 7 and Sir W. Abney. All these gentlemen have served as chairmen of the council, and the society owes them much.

Both institutions are financially strong. The London Institution possesses a site which is worth at least $\mathrm{I}_{50,000 l}$, besides a fund invested in consols of the present value of $3 \mathrm{r}, \mathrm{oool}$. Its income in 1903 was $3583 l$, and its expenditure was $3616 l$. The Society of Arts has an annual income which last year exceeded xI,000l., a capital fund of about $20,000 l$., which has accumulated from surplus income during the last twenty years, and trust funds amounting to nearly ${ }_{15}, 000 l$. What, then, are the inducements to the one institution and the other to consent to an amalgamation? It is not proposed that either should absorb the other. The suggestion is amalgamation into a single body for the promotion of science, art, and literature, and their practical applications, the members of each corporation preserving all their present rights, and sharing in the government of the new institution and in the direction of its future action.

The determining consideration with the Society of Arts is that the amalgamation would give it a permanent local building. The society does not own its premises. They were built for it by the Brothers Adam in 1774 , but the lease has run out, and it is now practically a tenancy at will. Moreover, the building is inadequate for the growing needs of the society, and the funds at its disposal are not sufficient to enable it to build for itself, whereas by amalgamation with the London Institution, which would sell its Finsbury premises, ample funds would be available. It is believed that the accommodation required could be got for a sum of Ioo,oool., and a suitable site found "east of Charing Cross and west of Chancery Lane." If it were decided to erect a building of sufficient size there are several other societies who would probably be prepared to join in the scheme, separate and distinct accommodation being provided for each, much as Burlington House now accommodates a number of independent institutions.

The amalgamation would give the London Institution a large accession of annual income, and the revenues of the new institution would justify the extinction in perpetuity of the annual payment of two ruineas now required from the proprietors of the london Institution, while leaving them a permanent property in their shares disposable by will, or otherwise, as herctofore, the Society of Arts having approved of this as one of the terms of amalgamation. It would be part of the arrangement that any proprietor preferring to withdraw from the scheme and to surrender his share would be enabled to do so, and be paid 25 . in discharge of his rights and interests in such share. Those who remained would be members of an institution of very great importance and influence, well endowed, and in a position to carry into effect many objects of the highest public, scientific, and economic importance.

It is not to be supposed that the proposed amalgamation will be carried through without encountering opposition, but it will probably be found that a very large majority of both institutions is prepared to accept it. In the opinion of eminent counsel, the effect of its charter is to constitute the London Institution in a legal sense a charity, with the result that its property and funds are impressed with a charitable trust, and cannot be divided or applied to any other purpose than that prescribed by the charter. Consequently, the property could not be divided up without serious risk. If the amalgamation is to be carried through, the most convenient and least costly way of carrying it into effect would be to promote an Act of Parliament for the purpose, and, cranted the authorisation of general meetings, this will be done. But an Act cannot be got 
until next year, and a site for the new building can hardly be secured before the Act is got, so that if all goes smoothly, a year or two must elapse before the united societies, to be known as "The Society of Arts and the London Institute," can receive their friends under the altered conditions, and in their new premises.

The idea of thus combining into a single body two scientific institutions, each of considerable importance, is a bold and novel one, and it is to be hoped that it may not fail of success. It would be a pity if any narrow views or selfish considerations hindered the carrying out of a very interesting experiment. Each of the two corporations can supply much of what the other lacks. The constitution of the London Institution is unfortunate. It consists of a body of shareholders, the descendants or heirs of the original founders, many of whom are naturally out of sympathy with the objects of the institution, and no means exist of introducing fresh blood or attracting to its membership the men who would most fitly carry on its proper work. Very early in its career the kindred Royal Institution altered its constitution, disendowed its pro prietors, and adopted a more popular and democratic organisation. Its unfailing success ever since has proved the wisdom of the change. But the Finsbury institution possesses considerable property. It has a magnificent library. Its list of members is still a showy one. It only requires the infusion of fresh blood; it wants new life and vigour. The Society of Arts is a very popular and vigorous body, full of life and energy. It does much really useful public work. Its examinations, for instance, attract more candidates than that of any other private body in the kingdom. Its Cantor lectures (which are always freely open to London students) are a valuable educational agency. But it is hampered by want of larger offices, its library is far from being a credit to it, and it might well devote more attention and more funds to purposes of research and investigation.

A new institution such as should be formed ought to possess the good points of both its parents, while avoiding the weaknesses of either. It might also form a nucleus round which might gather many of the smaller societies, now often inadequately housed. In a suitable building accommodation might well be provided for many other societies, scientific, literary, and artistic, which are now scattered about in various quarters of London.

Even a larger scheme is conceivable. Burlington House can find room for but a small proportion of the scientific bodies of London. Why should not this proposed amalgamation lead to the erection of a second Burlington House, of which those of our larger and richer societies who are not satisfied with their premises should erect each their own part, independent certainly of one another, and yet combined under a common roof?

\section{NOTES.}

LORD KELVIN, who has been out of health for some time, underwent a serious operation on March 29. $\mathrm{He}$ passed a restless night on March 30 , but has much improved since then, and appears to be making satisfactory progress toward recovery. The King and the Prince and Princess of Wales have made special inquiries as to his condition; and there have been numerous callers.

Sir Wrlliam Ramsay, K.C.B., F.R.S., has been elected a member of the Athenæum Club under the provisions of the rule which empowers the annual election of nine persons " of distinguished eminence in science, literature, the arts, or for public services."

NO. I 849 , vOL. 7 I]
IT is reported by the Exchange Telegraph Company that a violent earthquake occurred at Lahore on Tuesday, April 4, causing serious loss of life and great damage to public buildings and other property.

A GRANT of $30,000 l$. has been authorised by the Carnegie Institution, Science states, for the solar observatory on Mt. Wilson. It is expected that the first equipment will cost about twice this sum.

We learn with sincere regret that Prof. Pietro Tacchini, formerly director for many years of the astronomical observatory of the Collegio Romano, and of the Central Office for Meteorology and Geodynamics at Rome, died on March 24 at sixty-seven years of age.

THE Times states that the Chartley herd of white cattle has just been purchased by Mr. J. R. B. Masefield, of Cheadle, Staffordshire, on behalf of the Duke of Bedford, who has come forward and saved the herd from leaving the country or falling into the hands of the taxidermist.

AN agricultural education and forestry exhibition will be held in connection with the show of the Royal Agricultural Society at Park Royal on June $2 \%-30$. Any offers of exhibits, or inquiries, should be addressed to the secretary of the society, at i3 Hanover Square, London, W.

THE Easter excursion of the Geologists' Association will be to mid-Lincolnshire. The party will leave London for Grantham on Thursday, April 20, and after visiting several places of geological interest will leave Lincoln for London on Wednesday, April 26. The excursion secretary is $\mathrm{Mr}$. W. P. D. Stebbing, 8 Playfair Mansions, Queen's Club Gardens, London, W.

A GREAT historical pageant is in active preparation at Sherborne, Dorsetshire, to commemorate the rooth anniversary of the founding of the town, bishopric, and school by St. Ealdhelm, A.D. 705. The pageant, which will be presented in the ruins of Sherborne Castle on June 12-15, will take the form of a folk-play written by Mr. Louis N. Parker and dealing with the chief historical events of the town.

True death of Dr. L. Bleekrode, of the Hague, is announced in the Chemical News. Dr. Bleekrode's work was principally connected with electrical matters, his first paper, in 1867 , being on the influence of heat on electromotive force. In 1870 he wrote a paper on a curious property of gun-cotton; other papers dealt with electrical conductivity and electrolysis in chemical compounds, observations on the microphone, \&c.

We regret to see the announcement of the death, on March 25, of the eminent German metallurgist, Prof. Bruno Kerl, at the age of eighty-one. He was professor of metallurgy at the Clausthal School of Mines, and subsequently at the Berlin School of Mines, and was the author of a number of metallurgical works. His first book, on the smelting processes of the Upper Hartz, was published in $185^{2}$. His important treatise on metallurgy was translated into English by Sir W. Crookes and E. Röhrig in 1868 . His books on assaying were also translated.

THE importance of the application of mathematics to engineering problems has frequently been insisted upon in these columns. Another instance of the close connection between pure and applied science is afforded by an investigation of some disregarded points in the stability of masonry dams, by Prof. Karl Pearson and Mr. L. W. Atcherley, referred to by Sir William Garstin in connection with the scheme for raising the Nile dam, in a recent 